\title{
Stress Sensitivity in Psychosis
}

Citation for published version (APA):

Vaessen, T. (2018). Stress Sensitivity in Psychosis: Assessment, Mechanism \& Intervention. [Doctoral Thesis, Maastricht University]. Gildeprint Drukkerijen. https://doi.org/10.26481/dis.20180613tv

Document status and date:

Published: 01/01/2018

DOI:

10.26481/dis.20180613tv

Document Version:

Publisher's PDF, also known as Version of record

\section{Please check the document version of this publication:}

- A submitted manuscript is the version of the article upon submission and before peer-review. There can be important differences between the submitted version and the official published version of record.

People interested in the research are advised to contact the author for the final version of the publication, or visit the DOI to the publisher's website.

- The final author version and the galley proof are versions of the publication after peer review.

- The final published version features the final layout of the paper including the volume, issue and page numbers.

Link to publication

\footnotetext{
General rights rights.

- You may freely distribute the URL identifying the publication in the public portal. please follow below link for the End User Agreement:

www.umlib.nl/taverne-license

Take down policy

If you believe that this document breaches copyright please contact us at:

repository@maastrichtuniversity.nl

providing details and we will investigate your claim.
}

Copyright and moral rights for the publications made accessible in the public portal are retained by the authors and/or other copyright owners and it is a condition of accessing publications that users recognise and abide by the legal requirements associated with these

- Users may download and print one copy of any publication from the public portal for the purpose of private study or research.

- You may not further distribute the material or use it for any profit-making activity or commercial gain

If the publication is distributed under the terms of Article $25 \mathrm{fa}$ of the Dutch Copyright Act, indicated by the "Taverne" license above, 


\section{Epilogue}

Summary 
This thesis contains work on stress sensitivity in psychosis. Although the stress response is adaptive in nature, it is involved in the developmental course of a broad range of somatic and mental illnesses.

Chapter one provides a general introduction to the concept stress and the role it plays in the development of psychosis. Psychosis is considered a mental illness that is characterized by loss of touch with reality. However, psychotic symptoms may vary considerably in terms of expression and intensity, forming a continuum. Exposure to stressors may sensitize those who have a genetic vulnerability, and put an individual at risk for developing psychosis and other paychopathology. The remainder of this thesis looks into the concept of stress sensitivity and its link to mental illness, with a main focus on psychosis.

Before we can study stress sensitivity in daily life, we need a valid way to do so. Chapter two describes methods of stress assessment in daily life and attempts to validate these using the "known group" method. This method is based on the knowledge about known group characteristics. ESM stress assessment was indeed able to distinguish between groups that are assumed to have higher stress reactivity and control groups. Furthermore, they are associated with biological measures, clinically relevant concepts, and factors that may explain the mechanism underlying increased stress reactivity. Yet, each method has its particular disadvantages and careful consideration is required when assessing ambulatory stress reactivity.

In chapter three, an original study is described that investigates the predictive value of increased affective stress reactivity for symptoms indicative of psychopathology. Increased stress sensitivity is thought to be a risk factor for a broad range of psychopathology, though the link between increased affective reactivity to daily stressors has hardly been investigated. The results show that only increased affective responses to minor hassles are associated with an increase in symptoms, one year later. As the stress response is a generally adaptive system, reacting with an increased in negative affect to daily stressors may actually reflect healthy behaviour. A similar response to the smallest of daily hassles, however, may reflect abnormal affective reactivity. However, the strongest predictor was overall negative affect, indicating that prolonged feelings of distress may constitutee the most acurate indicator of worsening mental health. These results build on the existing knowledge on the role of stress in the development of psychopathology and should be build-upon in future research.

Chapter four is a study on cortisol, a major stress hormone, in psychosis. As previous research showed psychosis to be associated with increased affective responsiveness to daily hassles, we were interested to see if we could find biological alterations as well. The results show that there are no differences in overall levels of cortisol between psychosis patients and their first-degree relatives or healthy control subjects. However, 
the cortisol response to daily stressors was blunted in both patient groups, showing that psychosis is associated with impaired HPA functioning. Patients who were taking antipsychotic medication did, however, not differ in their cortisol response from patients not currently taking antipsychotics, which suggests that this effect is not related to medication use. These findings point towards an impaired biological stress system that is apparent in everyday life.

Striatal dopamine, the most consistent biomarker for psychosis, has also been associated with stress. Chapter five presents a systematic review of the literature on dopamine release in the brain during stress. Although there is a shortage of studies investigating stress-induced dopamine release, patients with psychosis indeed seem to have more dopaminergic activity during stress in the striatum than healthy volunteers. Differences between stressor types may be accountable for differences in dopaminergic responses observed in the striatum. It is important that future studies try to replicate these findings and investigate where these differences come from.

Chapter six describes ACT in Daily Life - a treatment protocol that aids individuals in coping with daily stressors, based on Acceptance and Commitment Therapy. The implementation of skills and insights that are topic of any psychotherapeutic session in daily life remains a challenge. Ecological momentary interventions constitute a promising approach, in that they offer support in this process. The protocol described here uses the ground principles of Acceptance and Commitment Therapy - accepting negative thoughts and feelings that cannot be changed, and investing in one's values and reminds the individual of these principles via a smartphone app. Guided exercises help applying these principles in the moments where they are needed most: everyday life. Large randomized controlled trials must investigate the efficacy of this approach in the future.

Finally, chapter seven brings the findings of all previous chapters together in a general discussion on the three main themes of this thesis: assessment, mechanism, and intervention. Daily-life stress assessment is crucial for psychiatric research, but to date there is no consensus on how to do so. In this discussion, methods of ambulatory stress assessment are critically evaluated and alternatives proposed. It also brings together results on different systems of the stress response, and attempts to integrate these findings based on the coherence/compensation model. Finally, intervention strategies are discussed that target stress reactivity, as well as considerations on future research. 